Creative commons User License: CC BY-NC-ND

Abstracted by: EBSCOhost, Electronic Journals Service (EJS),

Google Scholar, Directory of Open Access Journals (DOAJ),

Journal Seek, Scientific Commons,

Food and Agricultural Organization (FAO), CABI and Scopus
Journal of Agricultural Extension

Vol. 21 (3) October, 2017

ISSN(e): 24086851; ISSN(Print); 1119944X

http://journal.aesonnigeria.org

http://www.ajol.info/index.php/jae

Email: editorinchief@aesonnigeria.org

\title{
Benefits of Zucchini Crop Cultivation among Farmers in Oluyole Local Government Area of Oyo State
}

https://dx.doi.org/10.4314/jae.v21i3.6

\section{Badiru, Idris Olabode}

Department of Agricultural Extension and Rural Development. University of Ibadan, Nigeria E-mail: bodebadru@gmail.com, Phone: +2348034660732

\section{Moronkunbi, Sekinat Abiola}

Department of Agricultural Extension and Rural Development, University of Ibadan, Nigeria E-mail: rubyred4luv@yahoo.com, Phone: +2348077300714

\section{Abstract}

This study assessed the benefits derived from the cultivation of zucchini crop among farmers in Oluyole Local Government Area of Oyo State. Data were collected from 79 farmers on socioeconomic characteristics, access to information and knowledge of the potentials of zucchini cultivation as well as constraints to and benefits derived from zucchini cultivation. Frequency counts and percentages were used to describe the data. Majority of the farmers had minimum formal education (75.9\%) and over 10 years of farming experience (86.1\%). Many (46.8\%) had large household size (9 - 13 members), small holdings of $3-5.9$ hectares (63.3\%) and mostly (91.1\%) cultivated Middle Eastern zucchini varieties. Access to information on zucchini was mainly through zucchini merchants $(\bar{x}=1.76)$, extension agents $(\bar{x}=0.90)$ and radio $(\bar{x}=0.54)$. The majority $(60.8 \%)$ however, had low knowledge of the potentials of zucchini cultivation. The main constraints to its cultivation were inadequate storage facilities $(\bar{x}=1.96)$, low awareness of the value and potential of zucchini $(\bar{x}=1.95)$ and high cost of inputs $(X=1.24)$. The major benefit derived from the cultivation of the crop was increased income $(\bar{x}=1.94)$. There was no significant relationship between knowledge of the potentials and benefits derived from the cultivation of zucchini. Awareness campaign on the potentials of the crop should be created while farmers' capacity on appropriate storage technologies should be enhanced.

Key words: Zucchini farming, Exotic vegetables in Nigeria.

\section{Introduction}

The current global price of crude oil is compelling the Nigerian government to diversify from a mono-product to a robust, non-oil driven economy. The agricultural sector stands out in the non-oil sector of the economy due to its resilience over time. It has an enviable track record of being the major driver of the economy before the 
Creative commons User License: CC BY-NC-ND

Abstracted by: EBSCOhost, Electronic Journals Service (EJS),

Google Scholar, Directory of Open Access Journals (DOAJ),

Journal Seek, Scientific Commons,

Food and Agricultural Organization (FAO), CABI and Scopus
Journal of Agricultural Extension

Vol. 21 (3) October, 2017

ISSN(e): 24086851; ISSN(Print); $1119944 X$

http://journal.aesonnigeria.org

http://www.ajol.info/index.php/jae

Email: editorinchief@aesonnigeria.org

discovery of oil. In addition, it has consistently contributed a large chunk of the gross domestic product of the country even when oil prices were high (National Bureau of Statistics, 2016).

This recent shift in economic focus is bringing many investors, both young and old, to the agricultural sector of the economy (AFP, 2016). Therefore, there is a need to expose the intending farmers to as many profitable areas in agriculture as possible. One of these areas is the production of vegetables, especially the exotic ones. It is an area which is commanding a lot of attention in the agricultural sector because exotic vegetables are in high demand, and often requested for in places like big shopping malls, international hotels, multinational fast-food chains and high profile societies etc. They are also seemingly attractive to new farming entrants because they have short gestation period and high economic returns on investment (Ibeawuchi, Okoli, Alagba, Ofor et. al., 2015).

Some of these vegetables are already widely known and utilized. In fact, research, according to Rudrappa (2017) has also shown the health benefits of some of them. Latuca sativa (lettuce) for instance, is known to prevent osteoporosis, iron deficiency and believed to protect man from cardiovascular diseases. However, there are still some exotic vegetables which are of high economic value but less known among Nigerian farmers. A good example of such is zucchini.

Zucchini squash, also known as courgette, is one of the most popular summer squashes in the United States of America and Europe. Like gourds, it belongs to the Cucurbitaceae (cucurbita-pepo) family of vegetables. Zucchini can be dark or light green. A related hybrid, the golden zucchini, has a deep yellow or orange colour. In a culinary context, zucchini is treated as a vegetable. It is usually cooked and presented as a savoury dish or accompaniment. Botanically, zucchinis are fruits, a type of botanical berry, being the swollen ovary of a zucchini flower. Fruits, leaves and flower of zucchini and other cucurbita species are used as vegetables and their seeds are consumed roasted as snack food (Nolte, 2017; Wikipedia, 2017).

Some popular varieties of zucchini according to Foster (2015) include green zucchini, yellow zucchini, tatuma, costata romanesco, yellow squash, patty pan squash, cousa squash, zephyr squash and eight ball squash etc. (figure 1). Zucchini fruits are usually ready for harvesting about 40-50 days after planting.

Zucchini has a lot of economic importance in addition to its culinary use. It also has high nutritional and health benefits such as being an alternative treatment for cholesterol control programme. It helps to fight cancer, reduces painful symptoms of rheumatoid arthritis, reduces eye problem, minimises risks of heart problem and strokes and prevents neural tube defects during the early stage of pregnancy etc. (Organic facts, 2017; Reddy, 2017; Tremblay, 2013).

Despite these benefits/values of zucchini crop, there is scarcity of documented information about the crop in Nigeria. In addition, awareness about the crop is still very low. There is therefore a need to have adequate information on the benefits derivable from this crop, with a view to documenting such for wider dissemination among intending farmers. Hence, this study was designed with specific objectives to:

1. identify the socio-economic characteristics of zucchini crop farmers in the study area,

2. ascertain the varieties of zucchini grown ; 
Creative commons User License: CC BY-NC-ND

Abstracted by: EBSCOhost, Electronic Journals Service (EJS),

Google Scholar, Directory of Open Access Journals (DOAJ),

Journal Seek, Scientific Commons,

Food and Agricultural Organization (FAO), CABI and Scopus

\section{Journal of Agricultural Extension \\ Vol. 21 (3) October, 2017 \\ ISSN(e): 24086851; ISSN(Print); 1119944X \\ http://journal.aesonnigeria.org \\ http://www.ajol.info/index.php/jae}

3. determine zucchini farmers' access to information on the production and marketing;

4. examine zucchini farmers' knowledge of the health and economic potentials of the crop; and

5. assess constraints faced by farmers in zucchini cultivation and marketing.

(a) Golden zucchini

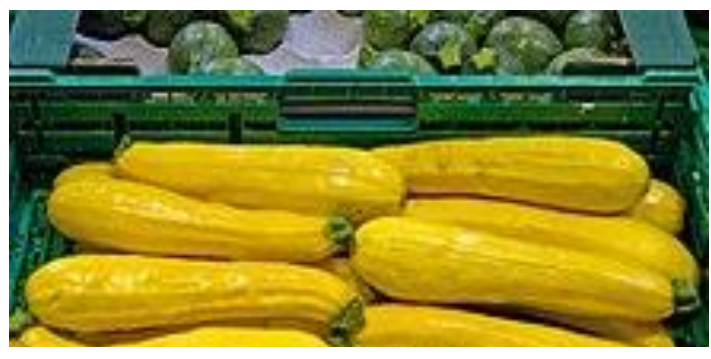

(c) Costata romanesco

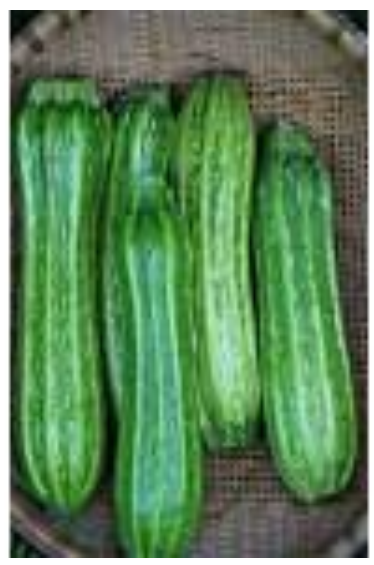

(b) Green zucchini

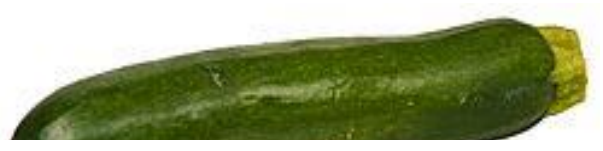

(d) Patty pan

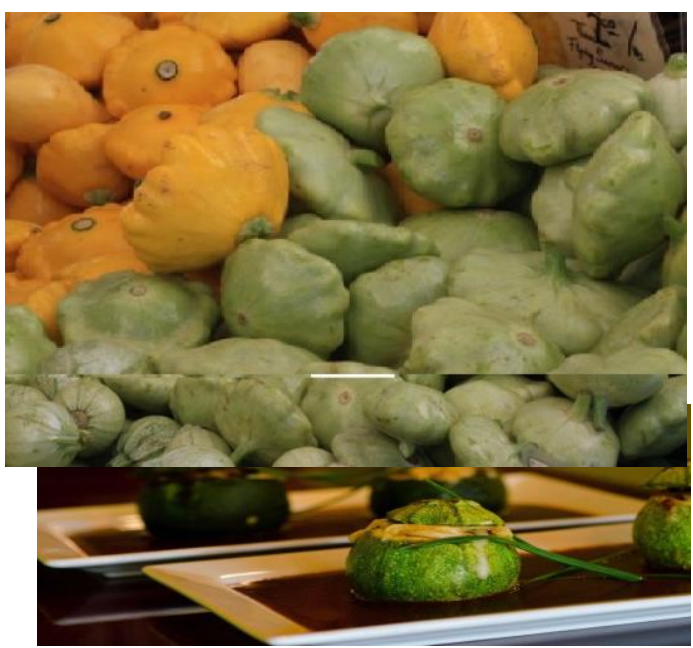

\section{Figure 1: Types of zucchini}

\section{Methodology}

The study was carried out in Oluyole Local Government Area (LGA), Oyo State, Nigeria. The LGA has one of the largest number of registered exotic vegetable farmers based on personal communication with the Director, Rural Institutions 
Creative commons User License: CC BY-NC-ND

Abstracted by: EBSCOhost, Electronic Journals Service (EJS),

Google Scholar, Directory of Open Access Journals (DOAJ),

Journal Seek, Scientific Commons,

Food and Agricultural Organization (FAO), CABI and Scopus
Journal of Agricultural Extension

Vol. 21 (3) October, 2017

ISSN(e): 24086851; ISSN(Print); 1119944X

http://journal.aesonnigeria.org

http://www.ajol.info/index.php/jae

Email: editorinchief@aesonnigeria.org

Development (RID) of the Oyo State Agricultural Development Programme (OYSADEP) on $1^{\text {st }}$ September 2015. Due to the absence of a separate list of zucchini farmers in the LGA, the community with the largest concentration of zucchini farmers i.e. Aba lbeji was targeted as the starting point for generating a list of zucchini farmers. Snowball technique was used to select a total of 79 zucchini farmers who were interviewed for the study. In addition, an in-depth-interview (IDI) was conducted with the leader of the zucchini farmers for a deeper understanding of the data collected.

Respondents were asked to tick the varieties of zucchini cultivated from a list of available zucchini varieties. Respondents were allowed to tick more than one variety which they cultivated. Simple frequency counts were used to analyse the emanating data.

Access to information sources on zucchini was measured by rating respondents' access to a list of available information sources on a three-point scale of always, occasionally and not at all. Always was scored 2 , occasionally 1 and not at all 0 . The weighted mean was computed and the information source with the highest weighted mean ranked $1^{\text {st }}$.

Knowledge of the potential of zucchini was assessed by providing respondents with a list of 17 knowledge questions cutting across areas like health, nutrition and economic potentials of cultivating zucchini. Respondents were asked to provide correct answers to the questions and correct responses scored 1 . The correct responses for each respondent were summed and a mean knowledge score generated. The mean knowledge was then used as a bench mark to categorise the respondents into high and low knowledge categories.

Constraints to zucchini cultivation were measured by asking respondents to rate the hindrances faced in the cultivation of the crop on a three-point rating scale of major constraint, minor constraint and not at all. Major constraint was scored 2, minor 1 and not at all 0 . The weighted means were thus computed as 1 . Constraints with scores above 1 were considered serious enough to hinder the sustainable cultivation of the crop.

Benefits derived from the cultivation of zucchini were elicited by asking respondents to rate the extent to which they benefited from zucchini cultivation using a three-point scale of to a large extent, to a lesser extent and not beneficial at all. To a large extent was scored 2 , to a lesser extent 1 and not beneficial at all 0 . Weighted means were generated using a bench mark of 1 and the emanating means used to rank the benefits derived from 1 to 5 .

\section{Results and Discussion}

\section{Socioeconomic characteristics of zucchini farmers}

A larger proportion of the farmers (45.0\%) were ageing according to Table 1 . This is further reflected in the mean age of 47 years which implies that there is a window of opportunity for the younger generation to fill the gap that may exist with time due to age. In addition, the majority of the respondents (87.3\%) were male in. This corroborates the finding of Adebisi-Adelani, Olajide-Taiwo, Adeoye and OlajideTaiwo (2011) that vegetable farming in another area of the State is male dominated. The low number of female respondents may suggest that women are not yet 
Creative commons User License: CC BY-NC-ND

Abstracted by: EBSCOhost, Electronic Journals Service (EJS), Google Scholar, Directory of Open Access Journals (DOAJ), Journal Seek, Scientific Commons,

Food and Agricultural Organization (FAO), CABI and Scopus
Journal of Agricultural Extension

Vol. 21 (3) October, 2017

ISSN(e): 24086851; ISSN(Print); $1119944 X$

http://journal.aesonnigeria.org

http://www.ajol.info/index.php/jae

Email: editorinchief@aesonnigeria.org

exposed to the potential of zucchini cultivation. This portends new job opportunities for the willing female farmers. Meanwhile, most of the farmers (83.5\%) were married. This suggests that familial demands could predispose them to look for ingenious ways to make ends meet. All the farmers were of either the Islamic or Christian faiths, although the majority was Muslims (67.1\%). This portends an opportunity for using the religious places of worship in advocating involvement in the enterprise as suggested by Badiru, Akande and Ladigbolu (2016) in another study with a similar finding. Although, there appeared to be an appreciable level $(75.9 \%)$ of basic formal educational attainment (primary and secondary education) in the study area, the proportion (32.9\%) considered literate enough (secondary education) was still low. It is even more disturbing to found close to a quarter of the farmers $(24.1 \%)$ who had no formal education at all. This could inhibit the prompt adoption of improved technologies that may be proposed in line with the assertions of Zegeye, Tadese and Tesfaye (2001). It was also revealed that many of the farmers $(54.4 \%)$ had large household sizes. This could be a cheap source of farm labour as well as being a source of pressure on the household head to explore sustainable ways of catering for the family. Furthermore, the majority of the farmers (86.1\%) had more than 10 years of farming experience which implies that they are knowledgeable about farming as an enterprise. Hence, their cultivation of zucchini could have been borne out of well informed decisions. Nearly all (97.5\%) of the farmers were small holders, a situation that is characteristic of farming in Nigeria. This could also be an incentive to new entrants into the enterprise as this suggests that the capital outlay may not be too much.

Table 1: Distribution of zucchini farmers based on socioeconomic characteristics

\begin{tabular}{clll}
\hline Characteristics & & Percentage & Mean \\
\hline \multirow{2}{*}{ Age } & $21-30$ & 23.0 & \multirow{2}{*}{47.1} \\
& $41-50$ & 32.0 & \\
Sex & $51-60$ & 45.0 & \\
& Male & 87.3 & \\
Marital status & Female & 12.7 & \\
& Single & 15.2 & \\
& Married & 83.5 & \\
Religion & Widowed & 1.3 & \\
& Christian & 32.9 & \\
Highest level of & Islam & 67.1 & \\
educational attainment & No formal & 24.1 & \\
& education & & \\
& Primary education & 43.0 & \\
& Secondary & 32.9 & \\
Household size & education & 43.0 & \\
& $4-8$ & 46.8 & \\
Farming experience & $9-13$ & 7.6 & \\
(years) & $14-18$ & 2.5 & \\
& $>19$ & 13.9 & \\
Farm size (ha) & $11-30$ & 78.5 & \\
& $>30$ & 7.6 & \\
& $1-2.9$ & 34.2 & \\
\hline
\end{tabular}

Source: field survey 2016 
Creative commons User License: CC BY-NC-ND

Abstracted by: EBSCOhost, Electronic Journals Service (EJS),

Google Scholar, Directory of Open Access Journals (DOAJ),

Journal Seek, Scientific Commons,

Food and Agricultural Organization (FAO), CABI and Scopus

\author{
Journal of Agricultural Extension \\ Vol. 21 (3) October, 2017 \\ ISSN(e): 24086851; ISSN(Print); 1119944X \\ http://journal.aesonnigeria.org \\ http://www.ajol.info/index.php/jae \\ Email: editorinchief@aesonnigeria.org
}

\section{Zucchini Varieties Cultivated in the Study Area}

Table 2 reveals that the Middle Eastern (91.1\%) and golden (72.2\%) varieties were the most cultivated zucchini varieties in the study area. This portends a supply job opportunity for the varieties in the community. The lower patronage of the round $(2.5 \%)$ and yellow crooknecks $(19.0 \%)$ varieties among the farmers could also portend an opportunity gap waiting to be filled by willing entrepreneurs after thorough feasibility studies have been carried out.

Table 2: Distribution of farmers based on variety of zucchini cultivated

\begin{tabular}{ll}
\hline $\begin{array}{l}\text { Varieties of } \\
\text { zucchini }\end{array}$ & Percentage \\
\hline Golden zucchini & 72.2 \\
Round variety & 2.5 \\
Yellow crook necks & 19.0 \\
Middle Eastern & 91.1 \\
\hline Source: field survey & $201{ }^{*}{ }^{*}$ multiple response options
\end{tabular}

\section{Access to Information on Zucchini Cultivation}

Table 3 shows that zucchini merchants $(\bar{x}=1.76)$ were the most important source of information on zucchini cultivation to the farmers. The finding was in agreement with the response of the group leader (IDI) that "we got the information about zucchini from the exotic vegetable merchants. They provided us with the seeds (they got from their foreign clients) and there is always a ready market for the produce". Extension agents and radio were ranked distant second and third respectively as information sources readily accessed by farmers for information on zucchini cultivation. The low rating of the two sources suggests a room for further improvement in the use of the two channels. It also implies that capacity building efforts at promoting zucchini cultivation in the area would have to involve the merchants as relevant stakeholders in the planning, implementation and evaluation stages. In addition, zucchini merchants could be veritable sources of information on the enterprise for willing entrepreneurs.

Table 3: Distribution of zucchini farmers based on access to information sources on the cultivation of zucchini

\begin{tabular}{|c|c|c|}
\hline $\begin{array}{l}\text { Information } \\
\text { sources }\end{array}$ & Mean & Rank \\
\hline Zucchini merchants & 1.76 & $1^{\text {st }}$ \\
\hline Extension agents & 0.90 & $2^{\text {nd }}$ \\
\hline Radio & 0.54 & $3^{\text {rd }}$ \\
\hline Newspaper & 0.34 & $4^{\text {th }}$ \\
\hline Model farmers & 0.18 & $5^{\text {th }}$ \\
\hline Friends & 0.08 & $6^{\text {th }}$ \\
\hline Television & 0.0 & $7^{\text {th }}$ \\
\hline
\end{tabular}

Source: field survey 2016 
Creative commons User License: CC BY-NC-ND

Abstracted by: EBSCOhost, Electronic Journals Service (EJS),

Google Scholar, Directory of Open Access Journals (DOAJ),

Journal Seek, Scientific Commons,

Food and Agricultural Organization (FAO), CABI and Scopus
Journal of Agricultural Extension

Vol. 21 (3) October, 2017

ISSN(e): 24086851; ISSN(Print); 1119944X

http://journal.aesonnigeria.org

http://www.ajol.info/index.php/iae

Email: editorinchief@aesonnigeria.org

\section{Knowledge of the health, nutritional and economic potentials of zucchini crop and farmers}

More of the zucchini farmers (60.8\%) had a generally low knowledge of the health, nutritional and economic potentials of the crop. (Table $4 \& 5$ ). However, the majority had good knowledge of its health potentials like lowering the risk of high blood pressure $(98.7 \%)$, strengthening of the immune system $(96.2 \%)$, reduction in the risk of heart diseases and strengthening of the eyesight (92.4\% each). They equally had knowledge of its nutritional potential such as being a substitute for fish/meat $(98.7 \%)$ and edibility of its flowers (81.0\%) and its possession of high water content $(100 \%)$. Farmers also knew that zucchini attracts foreign exchange (100\%) and is a source of reasonable monthly income $(98.7 \%)$. Capacity building efforts therefore needs to be directed at other areas of knowledge-lag such as local market demand for zucchini, its use in the treatment of other ailments, methods of consumption and cooking patterns for desired impact.

Table 4: Distribution of zucchini farmers based on knowledge of the potentials (health, nutritional and economic) of zucchini

Knowledge test items Correct responses

(\%)

Zucchini contains mineral elements that are good for lowering the risk of $\quad 98.7$ high blood pressure.

Consumption of zucchini can heighten the risk of heart disease. $\quad 92.4$

Zucchini consumption weakens the eyesight. $\quad 92.4$

Zucchini consumption strengthens the immune system. $\quad 96.2$

It can serve as substitute for meat/fish when used to make melon soup in $\quad 98.7$ vegetarian dishes.

It can be eaten raw without cooking.

5.1

Zucchini is used in the treatment of cough.

10.1

Only zucchini fruits are edible.

38.0

Zucchini can be planted throughout the year.

93.7

Eating overcooked zucchini makes the body healthy.

11.4

Highly bitter zucchini are the best for consumption.

5.1

Zucchini is cultivated mainly for the foreign market.

100.0

Highly reasonable income cannot be made from zucchini cultivation on a $\quad 98.7$

monthly basis.

Zucchini have long gestation period.

60.8

Zucchini flowers are also edible.

81.0

There is high local market demand for zucchini.

7.6

Zucchini has high water content.

100.0

Source: field survey 2016 
Creative commons User License: CC BY-NC-ND

Abstracted by: EBSCOhost, Electronic Journals Service (EJS),

Google Scholar, Directory of Open Access Journals (DOAJ),

Journal Seek, Scientific Commons,

Food and Agricultural Organization (FAO), CABI and Scopus
Journal of Agricultural Extension

Vol. 21 (3) October, 2017

ISSN(e): 24086851; ISSN(Print); 1119944X

http://journal.aesonnigeria.org

http://www.ajol.info/index.php/jae

Email: editorinchief@aesonnigeria.org

Table 5: Categorisation of zucchini farmers' knowledge scores

\begin{tabular}{llcccc}
\hline $\begin{array}{l}\text { Knowledge } \\
\text { level }\end{array}$ & Percentage & Mean & Minimum & Maximum & $\begin{array}{c}\text { Standard } \\
\text { deviation }\end{array}$ \\
\hline Low & 60.8 & 7.37 & 5 & 17 & 0.3 \\
\hline High & 39.2 & 7.37 & 5 & 17 \\
\hline
\end{tabular}

\section{Constraints to Zucchini Cultivation}

Table 6 shows that zucchini cultivation as an enterprise is constrained by poor storage facilities $(\bar{x}=1.96)$, low awareness of the value and potential of the crop ( $\bar{x}$ $=1.95)$ and high cost of inputs $(\bar{x}=1.24)$, among others. This is in line with the IDI finding that "zucchini is grown throughout the year. It is not limited by seasonality. However, we do not grow it on a large scale because there is no reliable way of storing/preserving it". This agrees with Nsikak-Abasi and Nkeme (2015), who implicated storage and processing barriers as impediments to agricultural production in Nigeria. Therefore, to sustain the cultivation of zucchini, these constraints would have to be addressed. From an entrepreneurial perspective, ideas to address these constraints could create opportunities for inventors of appropriate storage technologies/techniques or sale/distribution of existing relevant storage technologies and proven inputs to the farmers. In addition, packaging and distribution of easy to understand extension materials on the value and potential of zucchini crop could be a job outlet for willing entrepreneurs.

\section{Table 6: Distribution of zucchini farmers based on constraints faced in the crop's cultivation}

\begin{tabular}{lcc}
\hline Constraints & Mean & Rank \\
\hline Poor storage facilities. & 1.96 & $1^{\text {st }}$ \\
Low awareness of the value and potential of & 1.95 & $2^{\text {nd }}$ \\
the crop. & 1.24 \\
High cost of inputs. & 1.23 \\
High rate of postharvest losses due to poor & $3^{\text {rd }}$ \\
handling and storage. & 1.22 \\
Short shelf life of the crop. & 1.18 \\
High incidence of pests and diseases. & $4^{\text {th }}$ \\
Poor marketing distribution networks. & $6^{\text {th }}$ \\
Unavailability of other varieties demanded by & $7^{\text {th }}$ \\
merchants. & 1.14 \\
Unavailability of high quality seeds and & $8^{\text {th }}$ \\
planting materials. & 0.67 & $9^{\text {th }}$ \\
Unavailability of land and support services & 0.41 & $10^{\text {th }}$ \\
for large scale commercial production. & 0.27 \\
Overdependence on rains. & $11^{\text {th }}$ \\
\hline SOurce: field Survey 2016 & 0.27
\end{tabular}

Source: field survey 2016

\section{Benefits Derived from the Cultivation of Zucchini}

Table 7 reveals that economic considerations such as meeting the family needs and increase in income $(\bar{x}=1.94$ each), improved livelihood and food security $(\bar{x}=$ 1.84), improved employment opportunity $(\bar{x}=1.67)$ and access to new markets $(\bar{x}$ $=1.63$ ) were the benefits derived from the cultivation of zucchini by the respondents. The group leader also responded thus in an IDI; "we benefit a lot in monetary terms from zucchini production. We sell a kilogramme for about $\$ 500$ to the merchants". 
Creative commons User License: CC BY-NC-ND

Abstracted by: EBSCOhost, Electronic Journals Service (EJS),

Google Scholar, Directory of Open Access Journals (DOAJ),

Journal Seek, Scientific Commons,

Food and Agricultural Organization (FAO), CABI and Scopus
Journal of Agricultural Extension

Vol. 21 (3) October, 2017

ISSN(e): 24086851; ISSN(Print); 1119944X

http://journal.aesonnigeria.org

http://www.ajol.info/index.php/jae

Email: editorinchief@aesonnigeria.org

This could be a good incentive for going into any enterprise. It is expected that more people may be interested in opting for the cultivation of the crop as an enterprise if this reality is brought to their notice.

Table 7: Distribution of respondents based on benefits derived from the cultivation of zucchini

\begin{tabular}{lll}
\hline benefits derived & Mean & Rank \\
\hline Meeting some of the family needs. & 1.94 & $1^{\text {st }}$ \\
Increase in income & 1.94 & $1^{\text {st }}$ \\
Improved livelihood and food & 1.80 & $3^{\text {rd }}$ \\
$\begin{array}{l}\text { security. } \\
\text { Improved employment }\end{array}$ & 1.67 & $4^{\text {th }}$ \\
$\begin{array}{l}\text { opportunity. } \\
\text { Access to new market } \\
\text { opportunities. }\end{array}$ & 1.63 & $5^{\text {th }}$ \\
\hline
\end{tabular}

Source: field survey 2016

\section{Conclusion and Recommendations}

Farmers in the study mainly derived economic benefits from zucchini cultivation. They were however, not so knowledgeable about the health, nutritional and economic potentials of the crop probably due to accessing information on the production of the crop mainly form merchants who may only be interested in buying off every available produce from them. The farmers were further constrained by inadequate storage facilities among other challenges. Extension agencies are therefore enjoined to come up with awareness campaigns as well capacity building workshops on the potentials of the crop while, efforts at enhancing the farmers' capacity on preservation and value addition to the zucchini crop should also be explored.

\section{References}

Adebisi-Adelani, O., Olajide-Taiwo, F.B., Adeoye, I.B. and Olajide-Taiwo, L.O. (2011): Analysis of production constraints facing Fadama vegetable farmers in Oyo State, Nigeria. World Journal of Agricultural Sciences, 7 (2), pp. 189 - 192.

AFP (2016): Nigerians head back to the farm to beat recession. The Guardian newspapers, 04 September 2016. Retrieved from https://guardian.ng/businessservices on 16th April 2017.

Badiru, I.O., Akande, M.E. and Ladigbolu, T.A. (2016): Utilization of agricultural information on Ere Agbe Radio broadcasts among farmer-listeners in Oke-Ogun Area of Oyo State, Nigeria. Journal of Agricultural and Food Information, 17 (2-3), pp. $142-$ 150.

Foster, K. (2015): A visual guide to 8 varieties of summer squash. Retrieved from www.thekitchn.com on $16^{\text {th }}$ April, 2017.

Ibeawuchi, I.I., Okoli, N.A., Alagba, R.A., Ofor, M.O., Emma-Okafor, I.C., Peter-Onoh, C.A. and Obiefuna, J.C. (2015): Fruit and vegetable production in Nigeria: The gains, the

challenges and the way forward. Journal of Biology, Agriculture and Healthcare, 5 (2), pp. $194-208$. 
Creative commons User License: CC BY-NC-ND

Abstracted by: EBSCOhost, Electronic Journals Service (EJS), Google Scholar, Directory of Open Access Journals (DOAJ), Journal Seek, Scientific Commons,

Food and Agricultural Organization (FAO), CABI and Scopus

\author{
Journal of Agricultural Extension \\ Vol. 21 (3) October, 2017 \\ ISSN(e): 24086851; ISSN(Print); 1119944X \\ http://journal.aesonnigeria.org \\ http://www.ajol.info/index.php/jae \\ Email: editorinchief@aesonnigeria.org
}

National Bureau of Statistics. (2016). Gross Domestic Product of Nigeria, 2016 Q3. Retrieved from http://nigeria.opendataforafrica.org/NGNBSNGDPPTO2016/gross-domesticproduct-of- nigeria-2016-q3?indicator $=1000150$

Nolte, K. (2017): Zucchini. Retrieved from_https://cals.arizona.edu_on 16 ${ }^{\text {th }}$ April, 2017.

Nsikak-Abasi, A.E. and Nkeme, K.K. (2015): Barriers to increasing agricultural production in Nigeria. American Journal of Agricultural Science, 2 (4), pp. 138 - 143.

Organic facts (2017): Top 5 benefits of Zucchini. Retrieved from https://www.organicfacts.net on $12^{\text {th }} \quad$ April, 2017.

Reddy, V. (2017): 5 Surprising health benefits of Zucchini. Retrieved from www.vegkitchen.com on $2^{\text {nd }}$ March, 2017.

Rudrappa, U. (2017): Lettuce nutrition facts. Retrieved from www.nutritionandyou.com on $16^{\text {th }} \quad$ April, 2017.

Tremblay, S. (2013): The health benefits of Zucchini. Retrieved from www.livestrong.com on $16^{\text {th }} \quad$ April, 2017.

Wikipedia (2017): Zucchini. Retrieved from https://en.wikipedia.org/zucchini on 15th January, 2017.

Zegeye, T., Tadese, B., \& Tesfaye, S. (2001). Determinants of high yielding maize technology adoption: Empirical evidence from southwestern Oromia (Research Report No. 38). Addis Ababa, Ethiopia: Ethiopian Agricultural Research Organization (EARO). 